\title{
1977 geologic field investigations, Point Lay area, North Slope, Alaska
}

Sherwood, K.W., and Amoco Oil Co.

GMC DATA REPORT 445

This GMC data report from the Amoco Heritage collection has been made available through funding from the FY2018 USGS National Geological and Geophysical Data Preservation Program, Grant Number G18AP00054. This project report is presented in its original format and has not been reviewed for technical content or for conformity to the editorial standards of DGGS. It should not be used or cited as reviewed data.

2019

State of Alaska

Department of Natural Resources

Division of Geological \& Geophysical Surveys

GEOLOGIC MATERIALS CENTER
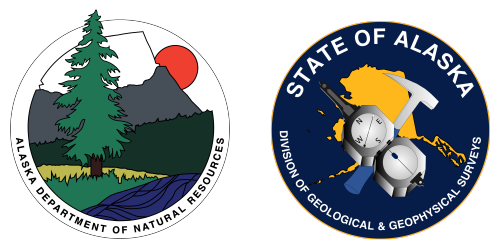
Amoco Production Company

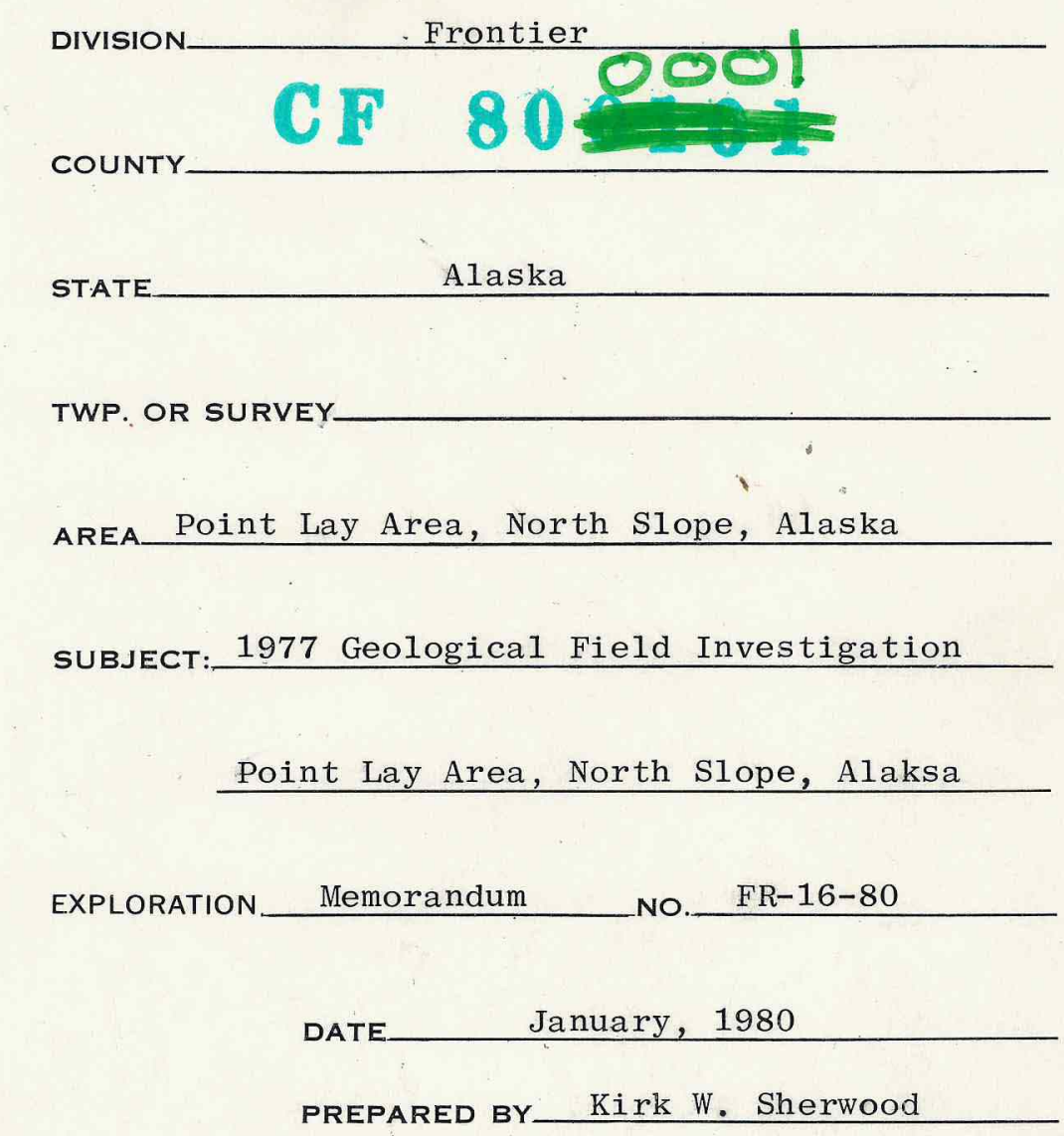

\section{ENCLOSURES:}

1. Index Map $\left(1^{\prime \prime}=16,000^{\prime}\right)$

2. Measured Sections (W-11 to $\mathrm{W}-26$ )

3. Environmental Interpretation Chart

4. Core Analysis Data

5. Source Rock Analysis
9. Literature

10. Paleocurent Data

11. Correspondence

12. Paleontological Data

13. Palynological Data

14. Palynological Data

15. Sample Lists and Tech Service Re

8. Field Photographs

EXPLORATION AUTHORITY(S) 


\section{CF 800101}

C, M, Richard

CHICAGO - MC 4604

Transmitted herewith is a copy of Frontier Division Geological Memorandum No. FR-16-80, reporting geological observations obtained during a field excursion into the Point Lay area of northwestern Alaska.

The report focuses upon the stratigraphy and reservoir quality of the Nanushuk sandstones of Cretaceous age deposited in a deltaic system which prograded northward from the Brooks Range. Source rock analysis of interbedded shales indicates gas or gas-condensate sources. Core analysis of 140 specimens of these sandstones yielded porosities averaging $6.3 \%$ and permeabilities averaging $0.39 \mathrm{md}$, indicating poor reservoir quality. Porosity and permeability measurements are based solely on surface samples and weathering effects may adversely affect these data. One well, the recently completed USGS-Husky Tunalik has log calculated porosities averaging $17 \%$ in the Kukpowruk sandstone of the Nanushuk group.

Subsequent drilling information from the NPRA will influence our recommendations concerning this area.

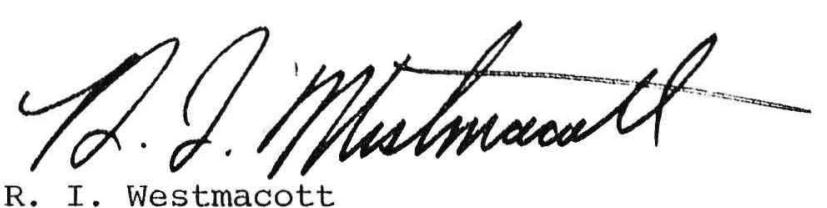

Frontier Division Exploration Manager

RIW : KWS : eg

Attachment

APPROVED FOR TRANSMITTAL:

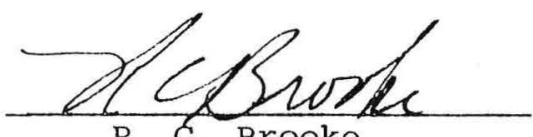

R. C. Brooke

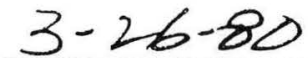

Date

AUTHOR: Kirk $W$. Sherwood 


\section{CF 800101}

January, 1980

Frontier Division Geological

Memorandum No. FR-16-80

"1977 Geological Field Investigation

Point Lay Area, North Slope, Alaska"

\section{INTRODUCTION}

CONCLUSIONS

RECOMMENDATIONS

LIST OF ENCLOSURES

GEOLOGICAL DISCUSSION

STRATIGRAPHY

Fortress Mountain Formation

Torok Formation

Kukpowruk Formation

Corwin Formation

RESERVOIR QUALITY

SOURCE ROCK POTENTIAI

STRUCTURE

REFERENCES

AUTHOR: Kirk W. Sherwood 
Amoco Production Company and Union Oil Company currently hold joint contractual rights to approximately 275,000 gross acres in the Point Lay-Western North Slope area, with the Arctic Slope Native Regional Corporation (ASNRC) as lessor. These leases carry a 10-year term, due to expire 28 February, 1987, with a firm well commitment beginning in 1982, As part of the evaluation of these lease-holdings, K. W. Sherwood participated in a joint Union-Amoco field program in the Point Lay area in the period July-August 1977. The field party conducted detailed measurements, description, and extensive sampling of the Neocomian to Albian Torok, Kukpowruk and Corwin Formations (Nanushuk Group). Exposures of the Neocomian or Albian(?) Fortress Mountain Formation near Tingmerkpuk Mountain were also examined. The Nanushuk Group and correlative rocks form the principal bedrock units in most of the surface and subsurface structures of the foothills and Arctic Plain north of the Brooks Range. The Nanushuk Group is the only known potential reservoir section at viable drilling depths beneath Amoco leaseholdings in the Point Lay area. The principal objective of this study was to try to identify porous sand facies within the Nanushuk Group, to determine their extent and trend, and to speculate upon their possible subsurface extrapolation into the leased area.

\section{CONCLUSIONS}

The Nanushuk Group in the Point Lay area does not appear to be prospective for the generation and entrapment of petroleum in economically viable quantities. The reservoir quality of all observed sand facies is poor, owing to limited depositional winnowing or sorting, post-depositional compaction of ductile clasts, and diagenetic mineralization. Core analysis of 140 specimens yielded an average porosity of $6.3 \%$, with values ranging from 1.0 to $16.0 \%$. Permeabilities are accordingly low averaging $0.39 \mathrm{md}$ and ranging from 0 to $8.6 \mathrm{md}$. One fractured sample yielded a permeability of $243.0 \mathrm{md}$. The results of the source rock analyses" are also discouraging, as all 120 specimens are rated as fair to very good gas or gas-condensate sources at an early peak gas stage of diagenesis. At present, gas is not an economical exploration objective in the remote Point Lay area.

\section{RECOMMENDATIONS}

As a consequence of the low priority assigned to the Point Lay Cretaceous project, no time has been made available for analysis and integration of the information gathered in 1977 with earlier field data or more recent drilling results. For this reason, this report is submitted as only a collection of field data and impressions, with no pretense at detailed analysis of the information. Accordingly, it is recommended that sufficient time and manpower be eventually appropriated to permit a complete stratigraphic evaluation of the Point Lay Cretaceous sequence. To date, no paleontological or palynological studies have been done, although such work is reportedly scheduled (personal communication Earl Armstrong) for the next 6-month period (January-July, 1980). This essential work must be completed before correlation of measured sections and further stratigraphic analysis can be carried out. Two wells have recently been drilled in the area (Chevron Eagle Creek \#l; USGS Husky Tunalik \#1), and a third test is currently being drilled by Chevron 13 miles south of Amoco lease holdings at Akulik \#l (see Enclosure 1). When the information obtained from these wells is eventually released, it should be integrated into the field data compiled in this report.

\section{LIST OF ENCLOSURES}

1. Index $\operatorname{Map}\left(I^{\prime \prime}=16,000^{\prime}\right)$

2. Measured Sections (W-11 to $W-26)$

3. Environmental Interpretation Chart

4. Core Analysis Data

5. Source Rock Analysis

6. Development Schemes and Economic Studies

(Enclosures 7-16 included only with Denver copy). 
7. Field notes

8 Field photographs

9. Literature

10. Paleocurrent data

11. Correspondence

12. Paleontological data (to be added when completed)

13. Palynological data (to be added when completed)

14. Field topographic maps

15. Sample lists and Tech Service Requests

\section{GEOLOGICAI DISCUSSION}

\section{Stratigraphy}

As defined and mapped by Chapman and Sable (1960), the Nanushuk Group is composed of three recognizable formations which collectively comprise a thick deltaic wedge that prograded northward from the Brooks Range during Albian time. The Nanushuk Group includes (from base to top) the prodeltaic Torok shale, the marine Kukpowruk sands and shales, and the non-marine coal-bearing sands and shales of the Corwin Formation. The Fortress Mountain Formation is a complex sand and conglomerate (Hunter and Fox, 1976) tongue enclosed within the Torok shale, and is generally not included with the Nanushuk Group. Each of the three formations in the Nanushuk Group is basically a facies component of the larger deltaic package (Figure 1), and is probably time-transgressive from southwest to northeast, as suggested from paleofloral correlations by smiley (1969, p. 2090).

The 1977 field effort was enbarked upon with two specific objectives: to try to identify porous sand facies within the Kukpowruk-Corwin sequence; and (2) to examine "orthoquartzites" previously reported by Union oil geologists from the Fortress Mountain Formation in the Tingmerkpuk Mountain area.

Core analysis of a small number of specimens gathered during a previous field excursion by Furer (1971) indicated that the Kukpowruk and Corwin sands possess little porosity and permeability. The 1977 stratigraphic studies focused upon the Kukpowruk Formation, for within this "facies" intuitively lay the greatest opportunity for development of extensive porous sands winnowed and deposited by nearshore marine processes.

\section{Fortress Mountain Formation}

The Fortress Mountain Formation was examined in detail at only two localities in the vicinity of Tingmerkpuk Mountain, Section $\mathrm{W}-12$ (Enclosures 1 and 2) typifies most exposures of Fortress Mountain rocks (Hunter and Fox, 1976) and consists largely of massive conglomerate in lenticular beds (photo R2/F6) up to 200 feet thick. The conglomerate contains rounded clasts of altered mafic and ultramafic rock, limestone', and chert derived from terranes to the south in the Brooks Range. The massive conglomerates have sharp upper and lower contacts and are enclosed within shale. The massive conglomerates contain thin, discontinuous beds of laminated pebbly sandstone and conglomeratic intervals exhibit both normal and reverse grading (photo $\mathrm{R} 2 / \mathrm{F} 5$ ). The reverse grading is not facies diagnostic, as i.t is a feature common to both high-energy braided stream-fanglomerate sequences and the highly channelized proximal or upper portions of submarine fans, However, also interbedded within the conglomerate-bearing shale are discrete beds of pebbly sandstone with sharp erosive bases replete with load structures and flute casts. The sandstones exhibit normal grading and the tops of beds are transitional upward into shale; internal convolution of bedding is also observed. These sandstones are interpreted as turbidites. The preliminary facies interpretation (see 
Enclosure 3) of the interbedded massive conglomerates thus favors a fan setting and suggests that the conglomerates are channelized "grain-flow" deposits or "fluxoturbidites" emplaced by down-slope mass movement of fluid-saturated sediment.

The Fortress Mountain Formation examined at Section W-11 (Enclosures 1 and 2) is quite different from Fortress Mountain elsewhere in that it contains no conglomerate and in that the sand exhibits an anomalously high quartz content. Most of these rocks would classify lithologically as quartz wackes or quartz arenites. No paleontological data is presently available to refute or confirm the correlation of this sequence wi.th the Fortress Mountain in section $W-12$, but as the depositional setting seems comparable, Section $\mathrm{W}-11$ is here included with the Fortress Mountain Formation. The sequence examined in Section $W-11$ has been referred to as the "Ting Sand" member of the Fortress Mountain by Chevron geologists and was cited in 1977 field conversations as the target objective of the Chevron Eagle Creek \#1 well (36-8S-45W; Enclosure 1).

At Section $\mathrm{W}-1 \mathrm{l}$, two distinct types of facies of sands can be recognized. The first group of sands range from 1 to 25 feet in thickness and exhibit systematic vertical textural trends and sequences of sedimentary structures typical of turbidites (Enclosure 3). These sands are interpreted as the product of channel overbanking into interchannel areas on the distal portion or "toe" of a submarine fan. The second type of sand locally appears to occupy channels and exhibits no clear systematic vertical sequence of sedimentary structures or textural trends. These sands have sharp, commonly-rippled tops, sharp bases, and exhibit internal convolution of stratification surfaces, Fluid escape pillars are rarely observed, and dish structures are fairly common. These features collectively point to deposition of the sand as a fluid-saturated slurry ("fluxoturbidite") emplaced as a downslope gravity flow. These sands range in thickness from 5 to 25 feet and are interpreted as active channel deposits in the lower parts of a submarine fan. These sands and the interbedded turbidites may both represent the "distal" equivalents of the upper fan or "proximal" massive conglomerates described from section W-12.

\section{Torok Formation}

The Torok Formation is a sequence of marine shale, siltstone, and minor sandstone which accumulated as a relatively shallow-water lutite apron peripheral to the prograding Nanushuk delta. Very little pure or fissile "prodeltaic" (deep-water) shale is observed within the sequence; most of the material termed "shale". is blocky and extremely silty. Intercalated with the shales are abundant interbeds of siltstone and minor very fine-grained sandstone. These beds are cross-laminated, burrowed and rippled, and suggest a relatively shallow-water depositional setting. Sandstone becomes progressively more abundant near the top of the formation where it is overlain by Kukpowruk sands. The sands in the upper parts of the Torok Formation range from 2 to 6 feet thick, have sharp bases, hummocky stratification (locally), abundant sole marks, graded bedding, and features related to soft-sediment deformation. These features collectively point to extremely rapid deposition by density flows (turbidity currents) probably spawned by storm and flood activity.

Intrafolial-style folds, faulting, and apparent minor unconformities are commonly observed within the Torok Formation exposures (see photos: R4/F4 and R4/F6). These structures are here interpreted as the product of syndepositional slumping, block rotation and mass movement of rapidly-deposited, fluid-saturated slope sediments.

\section{Kukpowruk Formation}

The Kukpowruk Formation is sandwiched between the prodelta marine shales of the Torok Formation and the overlying non-marine Corwin Formation, it represents the delta-margin or "delta-front" zone of transition between the two enclosing facies. Because of the transitional nature of the Kukpowruk Formation, the bounding contacts with enclosing formations are often difficult to place. The Torok Kukpowruk contact is most easily picked on aerial photographs at the transition from the smooth topography imparted by the Torok to the distinct trellis drainage or terracing created by kukpowruk outcrops. The Kukpowruk-Corwin boundary is extremely transitional (Chapman and Sable (1960) define a separate "transition" zone) but is by convention usually placed at the lowermost distinct coal bed. 


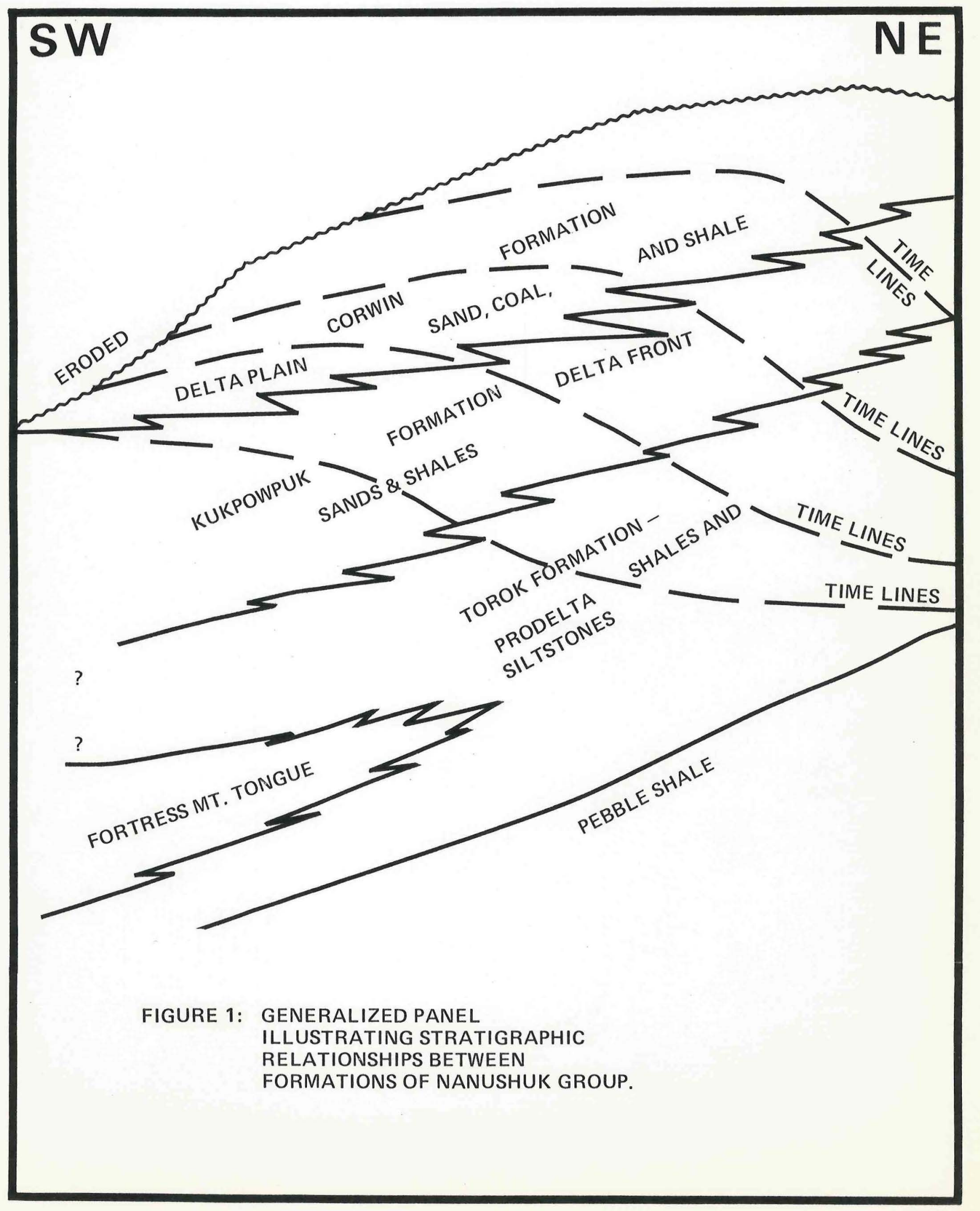


The Kukpowruk Formation contains a diverse array of sand-bearing facies, but by far the greatest amount of sand is stored in lenticular bodies deposited in distributary channels and as distributary channel-mouth bars. These deposits are incised into lower delta plain, brackish swamp and tidal flat sequences characterized more or less by the deposition of mud. Individual channel sand sequences range from 2 to 20 feet in thickness, but the processes of evulsion, abandonment, and reactivation have created composite or stacked channel sequences (photo R4/F12, 13, 14) from 40 to 100 feet in thickness (Enclosure 3).

The thicker composite bodies are usually traceable for at least several miles (photo R4/F8) perpendicular to paleocurrent transport directions (generally north to northeast). The distributary channel sequences are commonly incised into bioturbated or burrowed marine/brackish muds, and exhibit a systematic vertical sequence of sedimentary structures and textural trends. The lower parts (active-channel fill) contain medium-grained, moderately sorted pebbly sandstone, either massively bedded or exhibiting large-scale (set thickness greater than 1.0') trough-style cross-stratification. Mud-draped surfaces of lateral accretion (photo $\mathrm{F} 2 / \mathrm{F} 10$ ) on channel-mouth bars are rarely observed in this interval. This lower interval grades upward into very fine to fine-grained thin-bedded sands containing small-scale trough and tabular cross-stratification, wave and interference ripples. inter-bedded mud laminae, and 1ocal burrowing characteristic of partially-abandoned or abandoned upper channel fill sequences. The upper channel sequence, where not truncated by a superposed channel, grades upward into bioturbated interdistributary bay or tidal flat muds containing thin flaser interbeds of silty sandstone.

Evidence of reworking of sands by littoral marine (non-channel) process is only rarely observed in the Kukpowruk Formation. Only two forms of nearshore marine sands were recognized; these are identified on Enclosure 3 as high-energy and low-energy shoreface sands. These sands range from 10 to 30 feet in thickness and may be found in isolation or locally contained within a channel-mouth bar sequence. They are characterized, where complete, by a progradational sequence of silty, fine-grained, heavily bioturbated sand and mud which grades upward into fine-to medium-grained well-sorted sand containing swash-zone horizontal laminations or very low-angle wedge sets (photos R6/F26; R6/F27). High energy shoreface sands are generally coarser-grained and better sorted than low-energy shoreface sands, and may be truncated and capped by channel sand sequences.

In summary, the relative abundance of distributary channel sands and the relative absence of marine littoral sands suggest that the Nanushuk delta was a highly constructive delta. Extremely rapid northward progradation of the Nanushuk delta may have minimized the impact of marine shore processes, although it can alternatively be speculated that progradation was not necessarily rapid, but that a relatively high Barrow Arch to the north provided protection from the open ocean and limited the fetch in the leeward Colville seaway to the south. The general absence of littoral reworking and redistribution of sands has undoubtedly contributed to the observed low reservoir quality of Kukpowruk Formation sands.

\section{Corwin Formation}

Within the Corwin Formation, the only prospective accumulations of sand occur in point-bar (meandering-channel) sequences. Individual point-bar sequences range in thickness from 5 to 40 feet, but composite or stacked sequences may range up to 100 feet in thickness (photos R5/F19-26). The thicker composite sands are generally traceable laterally (photo $\mathrm{R} 5 / \mathrm{F} 6$ ) for approximately one mile perpendicular to paleocurrent transport direction (north to northeast), although one thick sand was traced for nearly 4 miles, Individual point-bar sequences are incised into marsh, swamp or levee muds and silts. The lower parts of the sequence consist of medium-grained sand with a pebble lag containing logs and other coalified plant debris on the basal scour surface. The lower interval is usually massively bedded or contains large-scale trough and tabular cross-stratification. The lower sand grades upward. Into very fine-to fine-grained sands with small-scale trough cross-lamination and climbing ripples. Where not truncated by a superposed point-bar sequence, the sands ultimately grade upward into abondoned-channel root-mottied silts and muds or coals (photo R3/F1, F2). 


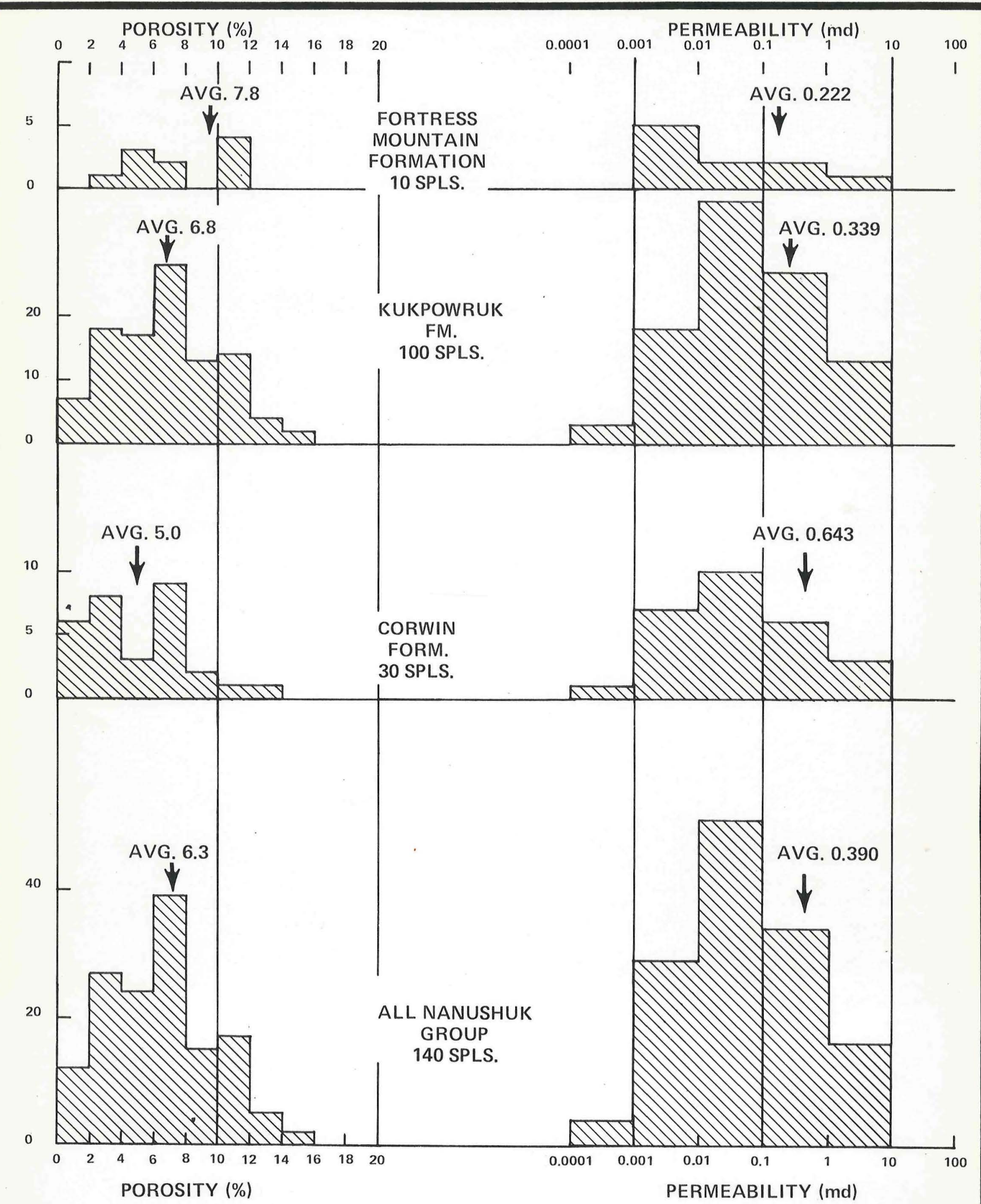

FIGURE 2: HISTOGRAMS SUIMMARIZING POROSITY AND PERMEABILITY DATA FOR FORTRESS MTN., KUKPOWRUK, AND CORWIN FORMATIONS 


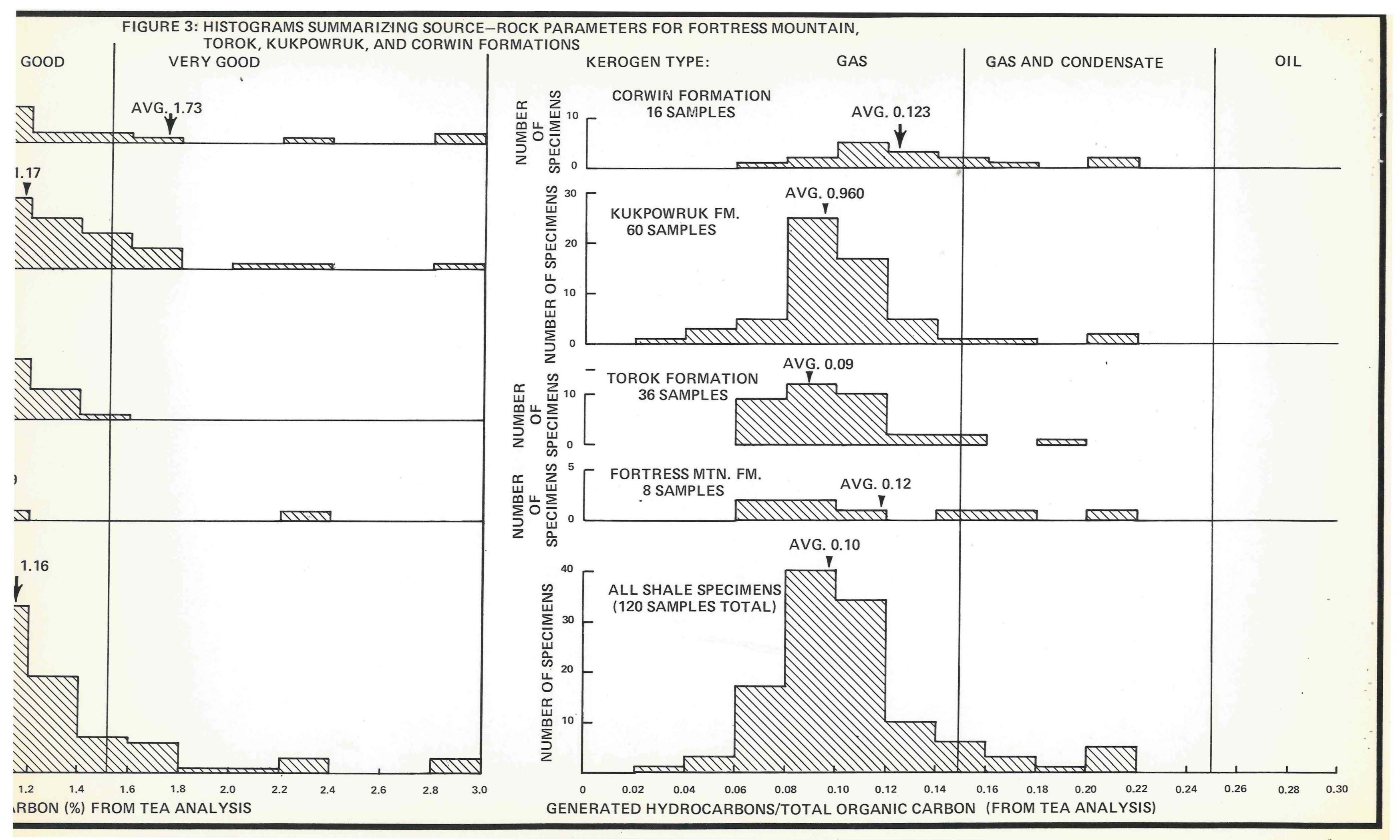




\section{Reservoir Quality}

of 140 sandstone specimens (see Enclosure 4) submitted for core analysis, only $24(17 \%)$ possessed porosities greater than $10 \%$, with an average porosity of 6.3\% for all specimens. Figure 2 summarizes the results of the core analyses in a series of histograms representing each potential reservoir formation. Summaries of core analysis data for individual facies are tabulated in one of the columns of the chart in Enclosure 3. Figure 2 shows that average porosities fall. within the range of 5 to $7 \%$ for the Kukpowruk and Corwin Formations, and examination of the core analysis breakdown in Enclosure 3 shows that no individual facies depart significantly from the gross formation averages. This data is corroborated by the results of recent extensive studies by the USGS (Ahlbrandt, 1979, p. 16-17). The most porous sands within the Corwin Formation are the point-bar sequences, with an average porosity of $5.4 \%$, ranging up to 12.2\%. Within the Kukpowruk Formation, sands of the distributary channel and channel-mouth bar facies yield an average porosity of $7.6 \%$ (range: $2.5-15.7 \%$ ) and an average permeability of $0.5 \mathrm{md}$ (range 0 to $3.5 \mathrm{md}$ ). Comparable porosities and permeabilities are observed (Enclosure 3) in the less abundant kukpowruk shoreface sands.

Within the Fortress Mountain Formation, the best reservoir properties are found in the well-sorted quartz arenite "fluxoturbidites" (described in Section W-11) of the "Ting sand member". These rocks yield an average porosity of $10.7 \%$ and an average permeability of $0.34 \mathrm{md}$. Only one specimen was analyzed from the conglomeratic Fortress Mountain, yielding a porosity of $4.5 \%$ and permeability of $1.0 \mathrm{md}$. Four specimens collected at other localities in the Fortress Mountain by Furer (1971) yield an average porosity of $7.2 \%$ (range: $5.6-9.0 \%$ ) and an average permeability of $1.18 \mathrm{md}$ (range: $0.05-4.47 \mathrm{md}$ ).

\section{Source Rock Potential}

Routine source-rock analysis has been conducted on 120 shale specimens collected from all formations examined during the 1977 field program. The technical service report is included here as Enclosure 5. Figure 3 summarizes the results of the source-rock analyses for each formation as a series of histograms for: (1), Total organic carbon (TOC); and (2), The ratio (Generated Hydrocarbons)/(TOC), as obtained from thermal evolution analysis. TOC provides one good index of petroleum generating capability and the TOC histograms of Figure 3 are presented with the source quality rating scheme conventionally used by industry. It is observed that most specimens are rated as fair to good sources with a minority rated as very good sources. (Generated Hydrocarbons)/(TOC) can be used as an index to identification of the type of hydrocarbon a specimen is likely to generate. This data is also summarized in Figure 3 along with categories for potential generators of gas, gas-condensate, or oil. The data indicate that the vast majority of samples are rated as gas sources with a few samples capable of condensate generation. The geochemical data is corroborated by ancillary studies of visual kerogen type, which classifies the kerogen content of most specimens as "structured" or, more rarely, "mixed". Carbonization levels are generally 4 or 5 and vitrinite reflectance (\%Ro) range from 0.56 to 1.28 , with the Corwin Formation providing the most immature specimens. These maturation levels correspond to the early peak gas stage of diagenesis. The high maturation levels indicated by these surface specimens suggest that past-peak levels of maturation are probably present at any significant depth in the subsurface.

\section{Structure}

As the chief objectives of the field study concerned the stratigraphy of the Nanushuk sequence, little or no observation of the structural details of these folded rocks was conducted. The gross structural patterns and fold style have been outlined by Chapman and Sable (1960). The folds somewhat resemble load structures and are cuspate in profile with broad, shallow synclines separated by sharp, narrow anticlines with steeply-dipping flanks and faulted crests. Some anticlines appear to verge slightly northward. In the axial parts of Snowbank Anticline (see photo R3/F5 and Section W-16, $0^{\prime}-300^{\prime}$ ) along the Kukpowruk River, numerous mesoscopic folds with subvertical axes were observed, suggesting vertical flow and diapirism of the shales in the core of the macroscopic fold, Seismic sections also suggest a mass displacement of Torok shale away from the axes of synclines 
toward the axes of anticlines above the decollement or zone of detachment. Diapirism and apparent thickening in the cores of anticlines may explain the uncommmonly thick Cretaceous sequences encountered in wells drilled on the crests of foothills-belt anticlines such as Amoco Aufeis \#1, Texaco Karupa \#1 and \#2, Mobil Beli \#1, Forest Oil Lupine \#1, Arco Susie \#1, etc. If a test well is eventually considered for one of the Nanushuk structures in the Point Lay area, a slightly off-crest or flank-ward location might be recommended in order to safely avoid a meaningless crestal test of structurally complex, diapiric core materials.

\section{REFERENCES}

Ahlbrandt, T. S. (ed.), 1979. Preliminary geologic, petrologic, and paleontologic results of the study of Nanushuk Group rocks, North Slope, Alaska. U. S. Geological Survey Circulate 794, 163 p.

Chapman, R. M. and E. G. Sable, 1960. Geology of the Utukok Corwin region, Northwestern Alaska: U. S. Geological Survey Prof. Paper 303-C, p. 47-174.

Collins, F. R., 1958. Test wells, Meade and Kaolak areas, Alaska, with micropaleontology of Meade test well \#I and Kaolak test well \#I, northern Alaska, by H. R. Bergquist. U. S. Geological Survey Prof. Paper 305-F, p. 341-376.

Furer, L., 1971. Preliminary geological evaluation of Point Lay area, western North Slope, Alaska. Amoco Prod. Co.: Denver Division Geological Memo \#145 (Amoco Vault File \#SV-71-0530).

Hunter, R. E. and J. E. Fox, 1976. Interpretation of depositional environments in the Fortress Mountain Formation, central Arctic Slope, in: Cobb, E. H. (ed.), the United States Geological Survey in Alaska - Accomplishments during 1975: U. S. Geolgoical Survey Circular 733, p. 30-31.

Smiley, C. J., 1969. Floral zones and correlations of cretaceous Kukpowruk and Corwin Formations, northwestern Alaska. AAPG Bull., V.53, p. 2079-2093. 